\title{
North Carolina Library Association Executive Board Meeting Minutes
}

\author{
April 23, 2010
}

\section{Attending}

Tammy Baggett (Director), Phillip Barton (Past President), Evelyn Blount (REMCO), Mary Boone (State Library), Pauletta Brown Bracy (LIT), Wanda Brown (VicePresident), Robert Burgin (Website), Phillip Cherry (REMCO), Carol Cramer (Finance), Steven Cramer (BLINC), Mimi Curlee (GRS), Cynthia Dye (YSS), Kem Ellis (LAMS), Jacqueline Frye (NCLPA), Jennifer Hanft (Membership), Ruth Hoyle (PLS), Jennie Hunt (WILR), Rebecca Kemp (RTSS), Emily King (NMRT), Priscilla Lewis (Operations), Rodney Lippard (ALA Councilor), Elizabeth Meehan-Black (SELA Representative), Jennifer Noga (CJCS), Timothy Owens (Constitution), Kim Parrott (Admin Asst), Mark Sanders (RASS), Ralph Scott (NCL Editor), Elizabeth Skinner (Director), Carol Walters (Public Policy), Carolyn Willis (CUS).

\section{Call to Order}

The meeting was called to order at 10:11 am by Phil Barton. Brian Thompson welcomed everyone. The agenda was approved. The minutes of the January 22, 2010 meeting were approved.

\section{Treasurer's Report}

Carol Cramer for Andrea Tullos

Budget will be filed as received.

\section{Section/Round Table Reports}

Business Librarianship Section

Steve Cramer: A workshop on the Economic Census was held on March 9 in Charlotte. Training on SimplyMap was held in Raleigh, Charlotte, Winston-Salem, and Greensboro in April. The AskBLINC service is active. More workshops are planned for the year.

College and University Section

Carolyn Willis: Planning continues for a joint CUS/ CJCL mini-conference in October. A workshop on student learning outcomes assessment is planned for May 21 at UNC-G. Bibliographic Instruction group officers have been named.

Motion: The NCLA Board approves the formation of a distance learning interest group under the NCLA College \& University Section.

There will be no additional fees for joining distance learning interest group if a member of CUS. CJCS members would be able to participate in distance learning interest group, though would not be considered a member of CUS for business purposes. The new interest group will have nonvoting representation on the CUS Board. An online discussion group for the new interest group was suggested. The motion was approved.

Community and Junior College Libraries Section Jennifer Noga: CJCS met and brainstormed on marketing and growing section membership. CJCS board discussed the upcoming joint conference with CUS in the fall.

Government Resources Section

Mimi Curlee: No report
Library Administration and Management Section Kem Ellis: LAMS board is planning a date to meet face-to-face, but will conduct a lot of business online. They are trying to brainstorm ideas on what to do this fall.

Literacy Roundtable

Pauletta Bracy: Motion: The Executive Board of the North Carolina Library Association supports the efforts of the Literacy Round Table to pursue an Office of the Governor proclamation of North Carolina Family Literacy Day. (The observance would be during Children's Book Week in November. The target audience is NC citizens. Promotion is through public and school libraries via a toolkit.)

LRT working on programming for the fall-one idea is family literacy day. The roundtable will distribute toolkit to public and school libraries. The motion was approved.

New Members Round Table: Emily King

Motion: The NMRT would like to make a motion for the board to approve our updated by-laws. The members of the NMRT approved these by-laws in October in accordance with our by-laws.

These changes are:

1. Re-wording of the by-laws to allow ballots to be collected via online submission forms.

2. Splitting the role of treasurer/secretary into two positions.

3. Re-naming of the Conference and Workshop standing committees to match the current activities of the New Members Round Table. The new standing committees are Conference/Workshop Planning and Mentoring Program. The duties associated with each committee were updated to match the new focus of each committee.

The full by-laws can be read at http://nclaonline. org/nmrt/nmrt-bylaws.

The motion was approved.

Networking dinners were held this quarter, some less well attended than they may have been in past. Possible reasons were inconvenient location or day. NMRT will partner with the membership committee more to visit Library Schools and promote NCLA. NCLA Board members (Mimi Curlee, Wanda Brown) who attended dinners this quarter said they enjoyed the dinner and networking opportunities. There was discussion about who is invited (all librarians) and ways to expand promotion and publicity for the events. The membership committee is working on a contact list to share with NMRT.

NC Association of School Librarians: VACANT

NC Library Paraprofessional Association Jackie Frye: NCLPA is trying to increase membership with small programs. They are working with ECU for a paraprofessional conference. They will work to ensure there is a membership table at the conference.

Both the membership committee and NCLPA are promoting the ALA/NCLA joint application.

\section{NC Public Library Trustees Association} VACANT

Public Library Section

Ruth Hoyle for MJ Goodrum: The Public Library Section has strong concerns regarding the 34\% reductions in Section and Roundtable cash balances that were recently implemented. If a priority for the coming year(s) is for Sections and Roundtables to boost membership, it seems counterproductive to handicap their ability to offer programs and workshops, which is the primary benefit that they offer to members. We have a particular concern for the ability of the smaller sections, whose fund balances may already have been quite small, to execute their missions with even less money available to them. That NCLA should find itself so suddenly, and seemingly unexpectedly, on such precarious financial footing is troubling. It suggests to us a lack of planning and foresight. The heavyhanded measure taken to address the shortfall was clearly a reactive, rather than a thoughtfully proactive, measure. It also seems arbitrary, disproportionate in its effects on different bodies 
within NCLA, and at the very least is clearly an unsustainable stop-gap solution to what must be regarded as a failure of process. We would like to see a total assessment of the overall NCLA budget occur, with a particular eye towards identifying which activities directly drive membership and meet the stated objectives of NCLA. Long term budgetary planning is paramount for the success of NCLA.

Hoyle recommended better orientation for new NCLA board members. Barton suggested inviting vice-chairs to attend a board meeting to acclimate them.

The PLS Board heard an update on the Charlotte/ Mecklenburg state of funding. Legislative Day is in Raleigh Wednesday May 19th (Hats Off to Libraries). The Board is exploring the possibility of a mini-conference day.

Anne Marie Elkins is retiring from the State Library; she is the expert on state aid, trustees, and much more. It will be a challenge to transition to a new person. The NCLA board discussed ways to honor her services to NCLA and the state.

Reference and Adult Services Section

Mark Sanders: The RASS board discussed ways to invigorate online presence and facilitate discussion/collaboration, possibly with Google Groups or other means of communication. They also brainstormed about a workshop in the fall and will meet next week to firm up ideas.

Resources and Technical Services Section

Rebecca Kemp: The sections is planning for a fall workshop-will try not to conflict with other groups. They have a new Google group. A Board member is leaving.

NCLA sections and round tables should use the web site resources (including the calendar) to 132 ensure that conferences do not conflict.

Round Table for Ethnic Minority Concerns:। Evelyn Blount: REMCO hopes to publish newsletter in late June. Two REMCO board members will work as membership representatives. The section is still looking for a webmaster.

Special Collections Round Table

Ralph Scott for Dale Sauter: SCRT is looking at ways to increase membership and considering a fall conference/workshop.

\section{Technology and Trends Round Table Ed Hirst: No report}

Women's Issues in Libraries Round Table

Jennie Hunt: The roundtable is seriously concerned with the way the finances were handled at the January board meeting, and they suggest that the board examines why this deficit occurred so that the same mistakes will not be made again. In particular, the roundtable suggests the board look at conference management and less expensive options for the Leadership Institute. It is WILR's opinion that the entire association can be weakened by taking money from the sections and roundtables, the organizations that drive the association and the biennial conferences.

The roundtable also discussed their fall workshop in Winston-Salem which deals with succession/ passing the torch, will be appropriate for public libraries.

Discussion about the January financial vote followed with other sections echoing the concerns expressed. Further discussion was postponed until after section and committee reports.

\section{Youth Services Section}

Cynthia Dye: The Youth Services Section would like to express our concern and dismay over the appropriation of $34 \%$ of each NCLA section's funds. We recognize that this action is within the rights of the executive board but possibly not in NCLA's best interest as a whole. NCLA should consider that many smaller sections struggle to provide programs and workshops, which increase membership, on limited budgets. This action also discourages sections from fundraising. YSS uses its funds to promote and provide a biennial retreat for Children and Youth Librarians and Specialists across the state. This retreat is used to increase membership, provide exciting programs, and add to the financial viability of YSS. We feel we have been fiscally responsible with the YSS funds. We are concerned that NCLA's budgeted spending is so far off its projected income. We feel this alone requires another look at the NCLA budget procedures and each line item to determine its support of the NCLA mission and its desire to increase membership. If increasing membership is of utmost importance, and we agree it is for the financial viability of the organization, then this may be the year that other expenses are put on hold or significantly decreased.

In other business, YSS discussed the North Carolina children's book award (nominations closed at the end of March) and the October 7-8 retreat at the Caraway Conference Center.

\section{Committee Reports}

Archives-Todd Nuckolls: No report

\section{Conference 2011}

Wanda Brown: The committee has not secured a venue yet. Six proposals were received; WinstonSalem, Concord, Greensboro, Greenville, Raleigh, Hickory are under consideration. The Committee is behind compared to previous years. The planning group will meet in September. If anyone is interested in assisting with conference, let Wanda know. They will be working on both the 2011 and 2013 conferences.
Constitution, Codes and Handbook

Timothy Owens: No report.

\section{Continuing Education-VACANT}

Finance

Carol Cramer: The Finance Committee is investigating moving scholarship money into the endowment fund to earn more interest. They also plan to determine if our non-profit status (501c3) is appropriate for the organization's mission and goals. Of special concern are our legislative day activities.

\section{Endowment}

Phil Barton will be the new endowment chair, while Bryna Coonin will continue to serve on the committee. The endowment, at the end of March had a balance of about $\$ 51,600.00$. This does not include the proceeds of the conference endowment dinner.

The board discussed pulling all endowed funds (scholarships, Roberts Award funds, etc.) into a single investment pool.

\section{Intellectual Freedom-John Harer: No report}

\section{Leadership Institute-VACANT}

Despite extensive promotion (at the biennial conference, over Institute website, Facebook group, and teleconference, only one application for the Institute has been received. (Application period closes May 1.)

The Institute normally receives $\$ 45,000.00$ of the $\$ 60,000$ needed from attendees and the rest from NCLA. A non-refundable deposit to Caraway Conference Center has already been paid. (Possibly Caraway will allow the Institute to reschedule without losing the deposit.)

An extended discussion followed touching on depleted travel budgets, the effectiveness and impact of the institute, marketing, opening participation to non-NC librarians, restructuring the institute, among others. Further discussion was postponed until after section and committee reports.

Membership

Jennifer Hanft: Recent Membership events include: Jennifer spoke/staffed a membership table at Wake County Public Libraries' Staff Development Day; participated in a panel discussion with Emily King, chair of NMRT, at UNC-SILS; and attended the two NMRT Networking Dinners in the Triangle this spring.

A new ALA/NCLA Joint Student Membership Application has been requested from ALA to replace the current expired application. The Membership Committee is working on a team approach to committee responsibilities, with individual committee member oversight of several 
initiatives, including working with section/round table representatives, library school/workplace recruiting visits, NCLA, and workshop/event administration. Membership Committee is working to help promote membership in NCLA's sections and round tables. They will continue to offer $\$ 5$ discounts on NCLA membership dues to anyone who joins or renews at an event (workshop, mini-conference, networking dinner, etc.), plus an additional free gift (NCLA t-shirt, mug, tote bag, etc.) to first-time members.

The committee feels it's very important for both current and lapsed members to hear from sections/ round tables they did not renew membership with, in addition to general letters NCLA Membership sends out. Section/round table representatives will be contacted soon to brainstorm on customizing letters to emphasize section/round table benefits, events, and opportunities for involvement. The committee is also working on ideas from Executive Board members: planning to roll out a survey to all expired members this July to determine reasons for not renewing membership and gather feedback on other aspects of the NCLA experience; they are also currently developing details on a membership drive which they plan to kick off this summer or fall. It will be promoted with an article in Tar Heel Libraries and information on the NCLA website as well as other marketing.

Discussion followed, including the possibility of membership vouchers for displaced librarians and a funding opportunities section of the NCLA website.

Nominating_Phil Barton: No report.

Operations

Priscilla Lewis: Kim Parrott's evaluation was completed in March. RFPs for 2011/2013 conference sites were sent out, among other activities.

\section{Public Policy}

Carol Walters: Library advocacy is critical-we must send a delegation to Washington DC. A review of the details for plans for June 28-29 legislative day in DC followed.

Scholarships_Lisa Williams: No report

\section{Website}

Robert Burgin: The first training for the Drupalbased website was held in February. Another training session is planned.

\section{Other Reports}

ALA Council

Rodney Lippard: NC voter turnout was low for ALA elections (17-18\%). Some people reported having trouble getting listserv messages about how to vote. Lippard will distribute information about the library bill of rights for prisoners and the Texas school board soon. Lippard met with UNC-G's foundations library school class, promoting both NCLA and ALA.

\section{SELA Representative}

Betty Meehan-Black: No report

\section{Editor, NC Libraries}

Ralph Scott: The March 2010 fall/winter issue released. The 2009 print issue has been sent to the printer, and should be ready to ship in about 30 days. The editorial board met at the conference in October and will meet again this summer. The editorial board explored the idea of members only web access to the journal, but felt everyone, member or not, should get access.

State Librarian

Mary Boone: Anne Marie Elkins is leaving the state library. Pam Toms, senior genealogy librarian, is leaving as well. The head of the cataloging unit, Kate Kluttz, is also leaving. The state library is losing very important people, there are lots of new library directors-there is a big generational shift going on in libraries across the state right now. Library development staff are busy. IMLS has given money to WebJunction to take the NC job search program national. There are 4 training sessions around the country-48 of 50 states on board.

Revisit discussion on budget:

The board further explored the idea of new board member orientation, especially to budget management and delaying the first board meeting of the biennium so that the board receives budget information (including a treasurer's report with conference fund information) a few days before the meeting.

Revisit discussion of Leadership Institute:

Robert Burgin made a motion to cancel 2010 Leadership Institute and focus on building the 2012 Leadership Institute, unless 45 applicants appear by the May 1,2010 deadline for application. The motion was seconded by Rebecca Kemp. The motion was approved.

The Board explored the amount of money already invested by NCLA (approximately $312 \$ 12,000$ ), options for recruiting participants, options for offering the Institute in another format, and the need to establish a committee to assess and support ongoing planning for the institute. If the Institute is cancelled, Kim will explore ways to salvage our Caraway deposit. Sherwin will need to terminate Mark Livingston's contract (by letter) before the 15th of July.

The meeting was adjourned at 2:11 pm.

\section{North Carolina Libraries}

Official Publication of the North Carolina Library Association

ISSN 0029-2540

The subscription cost to North Carolina Libraries is $\$ 50 / \mathrm{yr}$.

All issues are available online free-of-charge at

http://www.ncl.ecu.edu

Back issues are available from the North Carolina Library Association office at 1811 Capital Blvd., Raleigh, NC 27604, for $\$ 8$ an issue for those years prior to going online in 2002 , or $\$ 50$ for the annual print compilation beginning with

Vol. 60 (2002). 